\title{
Peculiarities of Usufruct in the Countries of Roman-German Law: Implementation of Best Practice in Ukrainian Law
}

\author{
Roman A. Maydanyk \\ Taras Shevchenko National University of Kyiv, Kyiv, UKRAINE \\ School of Law \\ Nataliia I. Maydanyk \\ Vadym Hetman National Economic University of Kyiv, Kyiv, UKRAINE \\ School of Law \\ Natalia R. Popova \\ National Academy of Legal Sciences of Ukraine, Kyiv, UKRAINE \\ F. G. Burchak Scientific and Research Institute of Private Law and Entrepreneurship
}

Received: 7 June 2021 - Accepted: 3 October 2021 • Published Online: 10 November 2021

\section{Abstract}

The article examines the features of usufruct in the European countries of Romano-Germanic law, determines the terms for the implementation of the best European practice of usufruct in the law of Ukraine. The law of European countries of continental law recognizes the usufruct as a real right of personal possession for use, which is considered an independent real right to another's property or a kind of easement. The peculiarities of usufruct in some countries of Romano-Germanic law, in particular in Germany, France, Georgia, Moldova and Russia, are researched. The peculiarities of usufruct in some countries of Romano-Germanic law, in particular in Germany, France, Poland, the Netherlands, Switzerland, Georgia, Moldova and Russia, are researched. The issues of usufruct implementation in the law of Ukraine are considered. The issues of usufruct implementation in the law of Ukraine are considered. The authors came to the conclusion that it is necessary to introduce the institute of usufruct into the Ukrainian law by supplementing the Civil Code of Ukraine with a new chapter "Uzufruct", the framework provisions of which are proposed in this paper.

Keywords: usufruct, quasi-usufruct, superficies, emphyteusis.

\section{Introduction}

In Ukraine, at the doctrinal and rule-making levels, the issue of introduction of the institute of usufruct, which is unknown to national law, is discussed. The Europeanization and the recodification of Ukrainian civil laws makes it necessary to study the best European practice in order to determine the optimal conditions for the implementation of the legal construction of the Usufruct.

(C) Authors. Terms and conditions of Creative Commons Attribution 4.0 International (CC BY 4.0) apply. Correspondence: Roman A. Maydanyk, Taras Shevchenko National University of Kyiv, School of Law, Kyiv, UKRAINE. E-mail: roman.maydanyk@gmail.com. 
The historical roots of usufruct originate in the property law of Roman law of the classical period. Usufruct and similar legal constructions (in the Digests of Justinian, they are all classified as personal easements) distinguishes among the special property rights of their strictly personal nature ${ }^{1}$.

The legal construction of the usufruct was received from Roman law into medieval continental law and is now considered a traditional type of limited property rights of many legal systems of continental Europe (Germany, France, Hungary, Italy, Switzerland), along with easement and building rights (emphyteusis).

The Law of Ukraine to real rights to another's property recognizes the right of possession, the right to use another's property (easement), the right to use land for agricultural purposes (emphyteusis), the right to build land (superficies) (Part 1 of Article 395 of the Civil Code of Ukraine), and also the right of economic management and the right of operative management (articles 136, 137 of the Economic Code of Ukraine). The usufruct is not provided by the law of Ukraine, despite the existence of a number of legal constructions similar to the usufruct.

When the current version of the Civil Code of Ukraine was adopted, there was no urgent need for the usufruct institute due to the lack of a developed land market. Modern civil legislation of Ukraine in terms of expanding the scope of private property rights has become necessary to develop and implement in the Civil Code of Ukraine generally accepted in world practice, the institution of usufruct.

The modern domestic civil doctrine discusses the idea of implementation the usufruct institute in the law of Ukraine, which is reflected in some scientific papers ${ }^{2}$ and in the provisions of the Concept of updating the Civil Code of Ukraine (the Concept of recodification), developed in accordance with the Resolution of the Cabinet of Ministers of Ukraine "On the establishment of a working group on recodification (update) of civil legislation of Ukraine” dated of 17 July 2019 № $650.3^{3}$

The above is due to the relevance of identifying best practices and conditions for the implementation of usufruct in the law of Ukraine. This study highlights usufruct in a Private Law of the Ancient Rome (4.1), the features of usufruct in the countries of Romano-Germanic law (4.2) and the conditions of implementation of usufruct in the law of Ukraine, taking into account the best European practice (4.3).

\section{The aim}

The aim of this paper is to study the peculiarities of usufruct in the Roman-Germanic Law countries and defining the conditions of its implementation in the Civil Law of Ukraine taking into account the best European practice.

\footnotetext{
${ }^{1}$ Doshdev, D. V. Rimskoye chastnoe pravo: Uchebnik dlja vuzov. M.: INFRA-M; NORMA, 1996. P. 415.

2 See: Maydanyk, R. A. Usufruct: European and Ukrainian Law // Problemy vdoskonalennja pryvatnopravovyh mekhanizmiv nabuttja, peredachi, zdijsnennja ta zahysty subjektyvnyk prav: materialy nauk.-prakt. Konf., prusvjach. Pamjati prof. Ch. N. Azimov ta 20-richu z dnja stvorennja kaf. zyv. Prava N 2 (Kharkiv, 29 lystop. 2019 r.). - Kharkiv: Pravo, 2019. - 396 s. S. 20-32; Smitjuh A. V. Schodo uzufrukta korporatyvnyh paiv (chastok, akzij) // PRAVO I SUSPILSTVO N 3 / 2020/ - S. 74-79. [Elektronnnyj resurs]. - Reshym dostupu: http://www.pravoisuspilstvo.org.ua/archive/2020/3_2020/13.pdf; Pavlenko O. O., Krasytska L. V. Usufrukt yak obmeshene rechove pravo // Visnyk studentskoho naukovoho tovarystva DonNU imenu Vasylya Stusa. Tom 1 N 5 (2013). S. 82-87. [Elektronnyj resurs]. Reshym dostupu: https://jvestnik-sss.donnu.edu.ua/article/view/1213

3 Concept of Updating the Civil Code of Ukraine. Kyiv: Publishing House 'ArtEk', 2020. 128 p.
} 


\section{Materials and methods}

The article is based on a provision of Civil Laws, the jurisprudence and scientific articles of the European countries of the Romano-Germanic law system. The research is grounded on dialectical, formal logical methods, methods of synthesis and analysis, comparative legal method and the method of modelling.

\section{Review and discussion}

4.1 Usufruct in a private law of the Ancient Rome

\subsubsection{Concept of usufruct}

The most important personal easement - usufruct ("usus" - use, "fructus" - fruit, growth, income) is defined in the Digests of Justinian as follows: "Ususfructus est ius alienis rebus utendi fruendi salva rei substantia" (D.7.1.1); translated from Latin usufruct is the right to use someone else's thing and remove the fruit from it while preserving the integrity of the substance (essence of the thing). 4

\subsubsection{Elements of usufruct}

In the private law of ancient Rome, the usufruct was the right to a corporeal thing, and its object was non-consumable things for their economic use, which should bear fruit (profit, income) to their holder. The objects of usufruct were also estates, part (room) of a house. The definition of the object of usufruct was essential in deciding the subject of the right's authorized person to remove the fruit from the used thing, as well as their distribution.

As a general rule, all the fruits of the thing belonged to the usufructuary. If on the basis of the legate the usufruct on real estate was granted, such as a building, the usufructuary owned all the income, rent for the buildings, courtyards, etc. that belonged to the building. The fruits from using the thing passed into the ownership of the usufructuary since the unilateral appropriation of the fruits. He had the opportunity to dispose of them because they became his ownership.

The right to use premises consisted of living in living quarters. The content of user rights was determined by the nature and purpose of premises. Depending on the basis of the right to live in a particular premises, the subject could use both the entire premises and its limited and separate part. The authorized person also had the right to use not only living space, but also places of common use in an apartment and an apartment building, use of ancillary premises, part of a common land plot.

\subsection{Features of usufruct in the countries of Romano-Germanic law}

\subsubsection{The concept of usufruct}

Usufruct (French: l'usufruit; German: Niessbrauch; Russian: pravo poljzovladeniya) is a real right of personal possession for use, which in the civil codes of many European countries of continental law is recognized as an independent real right to another's property (France, Italy, Spain, Georgia, Moldova) or a kind of easement (Germany, Austria). It should be noted that in

\footnotetext{
4 See: Novizkiy, I. B. Rimskoye pravo: Uchebnik dlya vuzov. M.: IKD 'Zerzalo-M’, 2008. Doshdev D. V. Rimskoye chastnoye pravo: Uchebnik dlya vuzov /Pod red. V. S. Nersesyanz. M.: Norma, 2003. S. 244.
} 
most countries - republics of the former Soviet Union there is no easement (in particular, Armenia, Belarus, Kazakhstan, Kyrgyzstan, Russia, Uzbekistan, Ukraine).

A usufruct is a real right to another's personal property, according to which a person owns and uses a thing in accordance with its purpose. The usufruct is provided by the owner of the immovable or movable thing to another person - a natural or legal person (usufructuary, possessor for use).

According to $\S 1030$ of the German Civil Code (BGB), a thing may be encumbered in such a way that the person in whose favor the encumbrance is established has the right to withdraw the benefit from the use of the thing (usufruct). 5

The French Civil Code (FCC) treats usufruct as the right to use things that belong to another person, in the same way as the owner himself, but only with the duty to keep their essence (Article 578 of the FCC). ${ }^{6}$

The Civil Code of Moldova (CC of Moldova) under usufruct recognizes the right of possession and use of one person (usufructuary) for a certain or definable period of time a thing of another person (nominal owner), receiving its fruits on the same terms as the owner, but with the duty to keep the essence of thing. The usufructuary has the right to own the thing, but cannot alienate it (Part 1 of Article 604 of the CC of Moldova). ${ }^{7}$

The fundamental difference between the usufruct and the right to build (superficies) is the preservation of the economic essence of the thing and the impossibility, as a general rule, of its change by the usufructuary. ${ }^{8}$

Thus, the essence of a usufruct as a property right is that its subject (usufructuary) takes the opportunity to use the burdened thing and extract from it fruits and income by ensuring its integrity and safety.

\subsubsection{The object of usufruct}

The object (subject matter) of usufruct can be any non-consumable property from which it is possible to extract useful properties (fruits and income): things - movable and immovable, proprietary rights, property complexes that are in civil circulation.

The thing, which is given in usufruct, can be used in both business and non-business activities. The usufruct extends to all the accessories of the thing provided in the usufruct, as well as to everything that joins it or is included in its composition.

It is inexpedient to narrow the range of possible objects of usufruct only by immovable things, as well as to prevent the use of the thing provided in usufruct in business activities. Otherwise, it will mean that the list of things that can serve as an object of usufruct will exclude movable property and property intended for business activities, such as single property complexes of enterprises, investment funds.

5 Grashdanskoye ulosheniye Germanii. Vvodnuy zakon k Grashdanskomu ulosheniyu: per. s nem. / sost. V. Bergman, M.: Infotropik Media, 2015. S. 339.

${ }^{6}$ Grashdanskiy Kodeks Franziyi (Kodeks Napoleona) - Code civil des Français (Code Napoléon) / per. S fr. V. N. Zahvatayev. M.: Infotropik Media, 2012. S. 203.

7 Grashdanskiy kodeks Moldovy. Zakon Respubliki Moldova, v redakziyi Zakona Respubliki Moldova N 133 ot 15.11.2018 g. // [Elektronnyi resurs]. - Reshym dostupa: http://www.legis.md/cautare/rezultate/112573 8 See: abz. 2 p. 7.1 Konzepzii razvitiya grashdanskogo zakonodatelstva Rossijskoq Federazii (odobrena Sovetom pri Presidente FR po kodifikazii o sovershenstvovaniyu grasgdanskogo zakonodatelstva 07.10.2009) // Vestnik VAS RF. 2009. N 11 // SPS ‘KosultantPlus. Pressa i knigi’. 
Along with the listed types of property, the object of usufruct can also be a share in the right of joint ownership, which means the possibility of establishing usufruct on the property right (construction "right to the right"). 9

As we know, in Roman law, within which the usufruct first arose, it was believed that its object could be any property that could bear fruit, produce and income. It is this principle that has formed the basis of German and French law, which, along with the construction "usufruct for things", provides for the construction "usufruct for rights".

However, in French law, the construction "right to a right" has a broader scope, as it can also be the object of transfer and alienation of property rights. This is confirmed by the fact that the French legislator recognizes as immovable property certain property rights, in particular, usufruct and easement, which are established on the immovable property (Article 526 of the FCC). In accordance with Article 581 of the FCC, the usufruct can be established on any type of movable or immovable property.

This means that from the point of view of the logic of the French legislator, the usufruct can be established on the usufruct. For example, a usufruct that is part of the inherited property of children may be encumbered by law by another usufruct in favor of the parents (Articles 382 and 387 of the FCC).

The German approach to this issue is different: only the rights of claim can serve as the object of usufruct. In Germany, the installation of usufruct on usufruct is strictly prohibited ( $\S$ $1059 \mathrm{~b}$ NCU).

\subsubsection{Types of usufruct}

Along with the classical Roman usufruct, the object of which were only individually defined, non-consumable things, European legal systems adopted from Roman law the construction of the so-called quasi-usufruct ("quasi usufructus"), according to which consumer things did not pass into possession and use (as in usufruct), but into the ownership of the authorized person. In modern European law enforcement practice, quasi-usufruct is carried out in cases of establishment of usufruct on: (1) property complexes, which include consumer things; (2) the rights of claim from obligations, the object of which are consumer things ${ }^{10}$.

Thus, the FCC and the NCU provide, along with the classic usufruct, the object of which are only individually-defined, non-consumable items, the construction of a quasi-usufruct (quasi ususfructus), which is established in relation to consumer items. Yes, according to Art. 587 FCC in the case of usufruct on consumer goods, the latter becomes the property of the usufructuary with the obligation after the end of the usufruct to return to the original owner of things of the same kind and quality or reimburse their value at a price determined on the day of return.

The main difference between the German quasi-usufruct and its French counterpart is that under German law, the usufructuary is obliged to reimburse the person who installed the usufruct for its value after the usufruct has been acquired. Under French law, the usufructuary has the right to choose between two options: he can either return to the owner an equal number of things he received of the same kind and quality, or reimburse their value. At the same time, if

\footnotetext{
9 Mazakyan, G. S. Pravo lichnogo polzovladeniya: problem teoriyi i praktiki: duss. ...kand. Yurid. Nauk. M., 2018. S. 9. [Elektronnyj resurs]. - Reshim dostupa:

https://msal.ru/upload/main/oodisser/2016/Matsakyan/\%Do\%94\%Do\%B8\%D1\%81\%D1\%81\%Do\%B5\% D1\%80\%D1\%82\%Do\%Bo\%D1\%86\%Do\%B8\%D1\%8F\%20\%Do\%9C\%Do\%Bo\%D1\%86\%Do\%Bo\%Do\%BA \%D1\%8F\%Do\%BD.pdf.

${ }^{10}$ Mazakyan, G. S. Ibid. S. 9.
} 
under French law, in order to reimburse the value of consumed items used price, which in comparable circumstances is usually charged for similar items at the end of the usufruct, then under German laws, the price that existed at the time of usufruct establishment. ${ }^{11}$

A special procedure applies in cases where the usufruct is established on the property complex, in particular on the enterprise.

In German civil law, it is considered that property right cannot be the object of any set (plurality) of things, such as the property of an enterprise, which includes things, rights and other property values (clientele, trademarks, etc.), because in this In this case, property within the meaning of $\S 903$ of the BGB may relate only to certain things that belong to the said sets. ${ }^{12}$

According to the mentioned approach, the usufruct on the property is established in such a way that the usufructuary acquires usufruct for each item that is part of that property (§ 1085 BGB).

The French legislature, on the other hand, declares the enterprise to be the sole object of usufruct, but with one caveat: if it includes consumer things, then they are covered by a quasiusufruct.

In some legal systems, a social usufruct is recognized as a kind of usufruct. Thus, according to the Russian Federation Bill № 47538-6 of 27 April 2012 (RF Bill) on amendments to the Civil Code of the Russian Federation, a social usufruct is a usufruct arising on the basis of a law or a court decision (paragraphs 1, 3 of Article 302.6 of the RF Bill).13

\subsubsection{Subjects of usufruct}

Two subjects are involved in the establishment of the usufruct: the authorized person, called the usufructuary, and the obligated person, who is usually the owner of the encumbered property. It is noteworthy that in Germany, the person who establishes the usufruct, along with the owner may be the rightful possessor of the thing.

However, in the interests of the usufructuary, it is presumed that the person who establishes the usufruct is the owner of the thing, unless the usufructuary knew that the person was not the owner.

In French and German law, usufruct can be established both for the benefit of individuals and for the benefit of any legal entity, regardless of the purpose of their activities. ${ }^{14}$

According to Russian law, only a citizen and non-profit organizations can act as usufructuaries (paragraph 11 of the RF Bill). In this regard, the Concept for the Development of

11 Gromov, S. A. Usufruct: yuridicheskaya konstrukziya I veschnoye pravo // Veschenye prava: postanovka problem i yejo resheniye: sb. St. / otv. red. M. A. Roshkova. M.: Statut, 2011. S. 197.

${ }^{12}$ Sukhanov, Y. A. Grashdanskoye pravo Rossii - chastnoye pravo. M.: Statut, 2008. S. 221.

13 See: Proyekt Federalnogo zakona N 47538-6 'O vnesenii izmenenij v chasti pervuju, vtoruju, tretju I chetvertuju Grashdanskogo kodeksa Rossijskoj Federazii, a takshe v otdelnyje zakonodatelnje akty Rossijskoj Federazii' (prinataya GD FS RF v pervom chtenii 27.04/2012) // SPS 'KonsultantPlus'.; Mazakyan G. S. Osobennosti pravovoj konstrukzii uzufrukta v rossijskom, germanskom I franzuskom prave // YUridicheskaya nauka. 2016. N 2. S. 58-65.

14 Mazakyan, G. S. Osobennosti pravovoj konstrukzii uzufrukta v rossijskom, germanskom i franzuskom prave // YUridicheskaya nauka. 2016. N 2. S. 61. 
Civil Legislation of the Russian Federation stated that the usufruct is established exclusively for non-commercial purposes and is provided to both organizations and citizens. ${ }^{15}$

In this regard, the position of the drafters of the Bill of the Russian Federation on resolving the issue of providing usufruct to non-profit organizations is not fully understood. Obviously, the sole purpose of establishing usufruct in favor of non-profit organizations can be considered the provision of housing to these persons for use as offices. It should be borne in mind that the validity of the usufruct of non-profit organizations may not exceed 21 years. ${ }^{16}$

\subsubsection{Term of usufruct}

Due to the personal nature of the usufruct may be established for a period not exceeding the death of an individual or the liquidation of a legal entity in whose favor the usufruct is established, if a shorter period is not established by law or contract (Part 1 of Article 606 of the Civil Code of Moldova).

The only restriction that applies to the range of subjects of usufruct concerns the maximum period of granting usufruct to legal entities. Thus, the $\mathrm{CC}$ of France and the CC of Moldova provide for the possibility of providing usufruct to a legal entity for a period not exceeding 30 years (Article 619 of the CC of France, Part 2 of Article 606 of the CC of Moldova).

The term of validity of the usufruct in French law by the parties may be made dependent on the attainment by a third party of a certain age (Article 620 of the CC of France). In Germany, such a restriction is not provided, so the usufruct, which is established in favor of a legal entity, is valid until its liquidation or until the alienation of the usufruct to another person. ${ }^{17}$

In accordance with Part 3 of Art. 606 of the CC of Moldova, any contract that establishes an indefinite and transferable in case of death or liquidation of the usufructuary usufruct, is void.

\subsubsection{Grounds for establishing usufruct. Causal and material model of installation}

The legislation of European countries, which provide for the institution of usufruct, allow different grounds for the right of personal right of use: on the basis of the agreement on the establishment of usufruct, due to a legate (testamentary disclaimer), due to law or court decision, etc. ${ }^{18}$

\footnotetext{
${ }_{15}$ Punkt 7.1 Konzepzii rasvitiya grashdanskogo zakonodatelstva Rossijskoq Aederazii (odobrena Sovetom pri Presidente RF po kodifikazii i sivershenstvovaniyu grashdanskogo zakonodatelstva 07.10.2009) // Vestnil VAS RF. 2009. N 11 // SPS 'KonsultantPlus. Pressa i knigi'.

${ }^{16}$ See: Proyekt Federalnogo zakona N 47538-6 'O vnesenii izmenenij v chasti pervuju, vtoruju, tretju I chetvertuju Grashdanskogo kodeksa Rossijskoj Federazii, a takshe v otdelnyje zakonodatelnje akty Rossijskoj Federazii' (prinataya GD FS RF v pervom chtenii 27.04/2012) // SPS 'KonsultantPlus'; Mazakyan G. S. Osobennosti pravovoj konstrukzii uzufrukta v rossijskom, germanskom i franzuskom prave // YUridicheskaya nauka. 2016. N 2. S. 61.

${ }_{17}$ Mazakyan, G. S. Osobennosti pravovoy konstrukzii usufrukta v rossijsom, germanskom i franzuskom prave // Yuridicheskaya nauka. N 2. S. 61.

${ }^{18}$ About it see: Germanskoye grashdanskoye ulosheniye ot 18 avgusta 1897 g. (s posled. izm.) // Germaskoye pravo. Ch. 1. Grashdanskoye ulosheniye. M.: MZFER, 1996; Grashdanskiy kodeks Niderlandov. Knigi 2, 3, 5 i 6 / Per. V. Fershtman; Otv. Red. F. J. M. Feldbrugge. 2-e iad. Lejden: Institut vostochno-yevropejskogo prava I rossiyevedeniya; Lejdenskij universitet, yuruduchesliy fakultet. 2000; Franzuskiy grashdanskuj
} 
In Part 1 of Art. 302.2 of the RF Bill provides for two grounds for the right of personal use, namely: under the contract (sale, exchange, gift, etc.), by inheritance on the basis of the will of the owner of the immovable property. In the first case, the written form of the contract is established by drawing up a single document signed by the parties, as a mandatory requirement for the validity of the establishment of the right of personal use. Since the right of personal use may be paid and free of charge, the agreement on the establishment of this right must contain the amount of the fee for the right of use or an indication of gratuitousness. If the right of use is established on a paid basis, the draft provides for a change in the agreement of the parties the amount of payment for the right of use not more than once every seven years, and in case of failure to reach an agreement - by court decision. According to Part 3 of Art. 302.2 of the RF Bill provides for a rule that the unified state register of enterprises contains information about the object of the right of personal use, the term, the fee for use and the obligations of the owner of the thing for the maintenance of this thing.

The bill provides for the establishment of a social usufruct, which arises on the basis of law or court decision. According to the set of qualifying features, social usufruct is recognized as a separate type of usufruct (paragraph 302.6 of the RF Bill).

The law of Ukraine adheres to the causal model (traditional model) of the transfer of legal title (France, Spain, etc.) peculiar to the countries of Roman law, according to which the basis for the transfer of property rights under a contract is a binding agreement that gives rise to obligations and property law. purchaser. The right in rem passes to the purchaser from the moment of its actual transfer, unless otherwise provided by the contract. The Central Committee of Ukraine does not provide for the construction of a property contract. The agreement on the establishment of usufruct by its legal nature is binding, which gives rise to property rights and obligations. There is no need to enter into a material contract that does not give rise to obligations in order to establish usufruct.

In this regard, the literature notes that such an approach encourages reflection on the related problem of competition, as the usufruct agreement gives rise not only to a right in rem but also to an obligation. This issue is resolved depending on which model of transfer of legal title is followed by the law of the country.

In countries that adhere to the abstract model of the transfer of legal title, the basis for the transfer of the real title is a material agreement that does not give rise to an obligation. Therefore, the transfer of property rights occurs on the basis of a property contract. Thus, in German law, the establishment of a usufruct provides for the need to enter into a property contract, which does not give rise to an obligation, ${ }^{19}$ which is a contract for the establishment of a usufruct.

Thus, if the object of usufruct is a land plot, then according to $\S 873$ of the BGB, the owner and usufructuary must first enter into a material agreement on the establishment of usufruct, then register it in the land register. Thus, the usufruct on the land arises on the basis of a specific legal structure, which includes two elements - the property contract and registration in the land book. ${ }^{20}$

In cases where it is a question of establishing a usufruct on a movable thing, it is necessary that the owner and the future usufructuary enter into a real contract and transfer the thing (§ 929 BGB).

kodeks, SPb.: Yuridicheskiy zentr 'Press', 2004. Shevejzarskoje grashdansjoye ulosheniye. Chast chetvertaya. Veschnoye pravo // Shurnal Ministerstva yustiziyi. 1908. N 8.

19 Vasilevskaya, L. Y. Ucheniye o veschnyh sdelkah po grasgdanskome pravu. M.: Statut, 2004. S. 360.

20 Vasilevskaya, L. Y. Ibid. S. 360. 
However, the law provides for certain exceptions to this rule. First, if the usufructuary already owns the object of usufruct, then the conclusion of one material contract is sufficient to establish the latter ( $§ 929$ BGB). Secondly, if the thing is owned by the owner, then its actual transfer can be replaced by an agreement of the parties (owner and person who acquires the usufruct) to establish the so-called possessory constitution (Besitzkonstitut). According to the possessory constitution, the person in whose favor the usufruct is established becomes the indirect owner of the thing ( $\$ 930 \mathrm{BGB})$.

In this case, the property contract includes a condition of entry into possession of the thing through the direct owner-owner and until the transfer of the thing to the future usufructuary has a special legal significance: in essence means the establishment of usufruct ${ }^{21}$. Finally, thirdly, if the thing is owned by a third party, its transfer can be replaced by a material contract, according to which the owner assigns to the person who acquires the usufruct, a claim for the extradition of the thing (§931 BGB). ${ }^{22}$

The establishment of a usufruct on rights is carried out in accordance with the provisions of the law on assignment of rights ( $§ 1069$ BGB). At the same time, the legislator draws attention to the fact that it is not allowed to establish a usufruct on a right that is not subject to transfer (paragraph 2 § 1069 of the BGB).

According to Art. 579 CC of France usufruct can be established on the basis of law or transaction (binding contract or will).

Characteristically, the $\mathrm{CC}$ of France, like Roman law, provides for two possible constructions of usufruct, which arises as a result of the law. In the first case it is a constitution directe par d'alienation, according to which the owner of the thing gives usufruct to another person, while retaining his title, and in the second case - a constitution par voie de retention, according to which the original owner transfers the thing to another person, making a reservation on the establishment of usufruct in their favor or in the interests of another person (Article 580 CC of France). ${ }^{23}$

The Constitution directe par d'alienation is used when the usufruct is established on the basis of a separate usufruct agreement based on payment principles, and the constitution par voie de retention is usually applied within a contract of sale or gift. Article 949 of the CC of France explicitly states that the donor has the right to reserve or transfer to another person the right to use or usufruct on the donated movable or immovable property.

\subsubsection{Grounds for termination of usufruct}

In civil law doctrine, the grounds for termination of property rights to another's property are traditionally divided into two groups: general and special. In turn, the German doctrine of law and legislation provides for the division of grounds for termination of property into two groups depending on the object of usufruct: termination of usufruct, which is established in relation to things, and usufruct on the right ( $\S 1061-1074$ BGB).

In French law, the general grounds for termination of usufruct include: (1) death of usufructuary; (2); waiver by the usufructuary of his right; (3) death of encumbered property; (4) expiration of the term for which it was established; (5) merger in one person of the qualities of the usufructuary and the owner; (6) non-use of usufruct for 30 years. As special grounds for

${ }^{21}$ Vasilevskaya, L. Y. Ibid. S. 360.

22 Mazakyan, G. S. Ibid. S. 62.

23 Antonov, B. A. Formirovaniye instituta usufrukta d germanskom prave: diss. ...kand. yurid. yauk. M. 2006. S. 57. 
termination of usufruct, the French legislator singles out the abuse of usufructuary rights, as well as the deterioration of encumbered property, as a result of which it becomes unusable for its intended purpose (Article 618 of the CC of France).

In German law, a usufruct established in respect of things is terminated in the event of the death of the usufructuary, the liquidation of the legal entity or legal capacity ${ }^{24}$ ( $\$ 1061$ BGB), the coincidence of the owner and the usufructuary ( $\$ 1063$ BGB), the usufructuary's waiver of his right ( $\S 1064$ BGB). A usufruct on a right, along with the grounds provided for in $\S \S 1963,1074$ of the $\mathrm{BGB}$, is terminated when the right encumbered by the usufruct is not a right to a movable thing (§ 1072 of the BGB).

In the RF Bill to the general grounds for termination of the usufruct must include the death (destruction) encumbered by the usufruct, the death of the usufructuary, liquidation or reorganization of a non-profit organization-usufructuary, expiration of the term stipulated by the parties, unilateral waiver of the usufructuary. Thus, the Bill of the Russian Federation admits a possibility of unilateral refusal of usufruct only if it has gratuitous character (paragraph 2 item 3 of item 302.5 of the Bill of the Russian Federation).

In addition, the RF Bill provides that the usufruct may be terminated on the basis of an agreement between the owner of the immovable property and the usufructuary or in court in the circumstances provided for in Art. 451 of the Civil Code (paragraphs 2, 3 of Article 302.5 of the $\mathrm{RF}$ Bill). In this regard, the literature draws attention to the fact that these circumstances are grounds for changing or terminating the contract for the establishment of usufruct, rather than grounds for termination of usufruct as a property right. ${ }^{25}$

The special grounds for termination of the usufruct may include the following: systematic non-payment by the usufructuary of the usufructuary fee, improper use of the encumbered thing by the usufructuary or systematic non-fulfillment of obligations to maintain the thing, as well as repeated or gross violation of the rules of use. Article 302.5 of the Draft Law of the Russian Federation).

The provisions of the RF Bill on the grounds for termination of social usufruct deserve attention. In accordance with paragraph 1 of Art. 302.8 of the RF Bill social usufruct, which is established in favor of persons living with the owner of the dwelling and have the right under family law to require this owner to pay alimony, is valid for the duration of the obligation of the owner of real estate to provide maintenance to such persons. Accordingly, the termination of the relevant obligation automatically entails the termination of the social usufruct. Social usufruct, which is established in favor of persons living with the owner of the premises and are dependent on the latter, is valid for life, unless otherwise provided by a court decision (paragraph 2 of Article 302.8 of the RF Bill).

Thus, the grounds for termination of such social usufruct are the death of the authorized person and the expiration of its validity. ${ }^{26}$

In accordance with Part 1 of Art. 302.5 of the RF Bill, the right of personal use terminates with the death of the user. From this we can conclude that the user cannot dispose of his right, including to transfer it by inheritance. An analysis of the civil law of other states shows an ambiguous approach to this issue. In particular, in countries such as Germany (§ 1059 BGB), Poland (Article 254 of the Civil Code of Poland), the Netherlands (Article 203 of Book 3 of the Civil Code of the Netherlands), Switzerland (Article 758 of the Swiss Civil Code) and others, the right of personal use is not transferred by inheritance. The prohibition on the transfer of the right of

${ }^{24}$ According to Clause $2 \S 1059$ a of the NCU, a capable company is equated to a legal entity.

25 Mazakyan, G. S. Ibid. S. 63.

${ }^{26}$ Mazakyan, G. S. Ibid. S. 62-63. 
personal use by inheritance is a characteristic feature of the legislation of the continental legal system. However, in Art. 595 of the CC of France, on the contrary, allows the free transfer of this right by inheritance. ${ }^{27}$

Termination of usufruct entails certain legal consequences. According to Art. 634 of the CC of Moldova, after the termination of the usufruct, the usufructuary is obliged to return to the owner the property he owns as a result of his right to the usufruct, in the condition in which it is. In case of death or damage to the property due to the fault of the usufructuary, the latter is obliged to reimburse the owner for the damages caused in this connection. If the usufruct is registered in the public register, the terminated usufruct must be excluded from it.

\subsubsection{Implementation and protection of usufruct}

Since the time of Roman law, the exercise of usufruct (exercitium juris) is considered a special, separate right from it, which can be transferred to third parties on the basis of paid or unpaid transactions. The specificity of the usufruct itself is that it, due to its purely personal nature, belongs to the category of those subjective civil rights that are not transferable and inalienable. This is reflected in the legislation of different countries.

Thus, in accordance with the legislation of the Russian Federation usufruct may be transferred to another person, including by universal succession or on the basis of a transaction. At the same time, the authors of the RF Bill leave unresolved the question of whether the usufructuary has the right to transfer to third parties the right to exercise the usufruct.

According to the BGB and the CC of France, the object of transfer and alienation can be both the usufruct itself and the right to exercise it. At the same time, the literature points to the inconsistency of German law in resolving the issue of the possibility of transferring the usufruct to third parties. Given the logic of the German legislature, it follows that the usufruct can be transferred to other persons only in cases where it is established in favor of legal entities. On the basis of a direct instruction of the law, the usufruct, which is provided to individuals, is recognized as non-transferable. Such persons have the right to transfer to other persons only the right to exercise usufruct (1059 BGB).

In French law, as a general rule, the transfer or alienation is carried out with the consent of the owner of the encumbered property. Exceptions to this rule are cases where the object of usufruct is a land plot intended for agriculture or real estate for commercial, industrial or craft purposes. In the absence of appropriate consent, the usufructuary has the right to enter into such an agreement on the basis of a court decision, if he proves in court that he does not harm the interests of the owner (Article 595 CC of France). The real problem in practice is the question of how the price of usufruct should be determined. According to the general rule provided by Art. $621 \mathrm{CC}$ of France, in the case of simultaneous purchase and sale of usufruct and ownership without the right of use, ${ }^{28}$ the price is distributed between the usufruct and this right in proportion to the value of each of these rights, unless the parties agree to include usufruct in the price. ${ }^{29}$

However, the Court of Cassation of France in its decision noted that the parties may use the proceeds from the sale of usufruct and property rights to purchase new property and thus

${ }_{27}$ Grebennikov, A. D. Pravo lichnogo polsovladeniya $v$ svete poloshenij, ustanavlivayemych proyektom Grashdanskogo kodeksa Rossijskoqfederazii // Notarius. 2012. N 5; Grebennikov, A. D. Right of personal usufruct in the light of the provisions established by the draft amendments of the Civil Code of the Russian Federation. URL: https://center-bereg.ru/b289o.html.

28 This means "naked property" (nue property), i.e., when due to the encumbrance of property by usufruct for the owner retains only his title and powers of disposal.

29 Grashdanskij kodeks Franzii (kodeks Napoleona) - Code civil des Français (Code Napoléon). S. 210. 
"restore" their rights to this property. In fact, in such situations the subject of the usufruct is replaced. In addition, it should be noted that since the usufructuary and the "naked" owner have completely independent property rights, they can alienate their rights to the same purchaser, in which case the property in the person of the latter again becomes full, unrestricted, and usufruct, on the contrary, ceases. ${ }^{30}$

Usufruct is protected by general and special ways to protect this type of property rights. Noteworthy is the law enforcement practice of establishing for usufruct a single universal method of property protection, which, in particular, is a confessional claim, which is widely used in the countries of Roman law.

The subject of the confessional claim are the following requirements: (1) recognition of the right of usufruct and assignment of possession of the relevant limited property right by claiming the encumbered thing from a third party, including the owner, who denies the existence of the right of usufruct; (2) elimination of obstacles (actions of a factual nature in the exercise of the right of usufruct), not related to the deprivation of usufructuary possession of the right of usufruct. ${ }^{3}$

\subsection{Implementation of the usufruct in the law of Ukraine}

\subsubsection{Similar to usufruct constructions in the law of Ukraine}

The law of Ukraine does not provide for the institution of usufruct and enshrines a number of property rights, which in nature and content are quite similar to usufruct.

Such rights include, first of all, the rights of family members of the owner of the dwelling (Article 405 of the CC of Ukraine), the right of the testator (legate) to use the testator's dwelling (Article 1238 of the CC of Ukraine) and the right to use someone else's land for agricultural purposes. needs, or emphyteusis (Articles 407-412 of the Civil Code of Ukraine).

A property right similar to a usufruct is emphyteusis, which is provided for in the CC of Ukraine (Articles 407-412), is emphyteusis - the right to use someone else's land for agricultural purposes. The content of the usufruct and emphyteusis constitute the right of possession and use of another's land, these property rights may be alienated, unless otherwise provided by law. Unlike emphyteusis, which arises on the basis of a contract, usufruct is established on the basis of a contract, will and court decision. Usufruct is a personal right that cannot be inherited. Emphyteusis may be inherited, except as provided by law. Emphyteusis and usufruct also differ in their subject. Emphyteusis is established in relation to agricultural land. The subject of usufruct can be a wider range of property - usually any real estate and movable property, unless otherwise provided by law.

A similar property right, which is provided for in the Land Code of Ukraine, is the right of permanent use of land, which provides for the right to own and use land that is in state or communal ownership, without setting a term (Article 92 of the Land Code of Ukraine). This right arises from the moment of issuance and registration of the relevant state act (Articles 125, 126 of the Land Code of Ukraine). The subjects of the right of permanent use may be only legal entities based on state or communal property and public organizations of disabled people of Ukraine, their enterprises (associations), institutions and organizations (Article 92 of the Land Code of Ukraine). ${ }^{32}$ According to some authors, the existence of the right of permanent use with a limited

${ }^{30}$ Mazakyan, G. S. Ibid. S. 64.

${ }^{31}$ Mazakyan, G. S. Ibid. S. 12.

$3^{2}$ Miroshnychenko, A. M. Zemelne pravo Ukrainy: Navchalnuy posibnyk. - K.: Instytut zakonodavstva Verhovnoyi Rady Ukrainy, 2007. S. 155. 
number of subjects is in conflict with the obligations of Ukraine to adapt Ukrainian legislation to EU law. In particular, from the point of view of EU competition law (Article 86.1 of the EU Treaty), the granting of the right of permanent use can be considered as state aid. Such assistance is allowed, but in limited cases and for a specific justified purpose.

The legislation of Ukraine for a short time (in 1990-1992) provided for the existence of a specific real right to land - "the right of lifelong inheritable possession." Thus, in accordance with Part 1 of Art. 6 of the Land Code of the Ukrainian SSR of 18 December 1990 (in the original version) "[in] lifelong inheritable possession of land is given to the citizens of the Ukrainian SSR for", in particular, "running a peasant (farmer) economy." This provision was duplicated in Part 1 of Art. 50 of the Code.

Subsequently, when presenting the code in the new wording of the Law of Ukraine of 13 March 1992 № 2196-XII, the mention of the right of lifelong inheritable possession was excluded from the code. However, the exclusion from the code of the rules on the right of lifelong inheritance of possession did not mean the termination of this right. As a subjective right, the right of lifelong inheritable possession of land, which arose at the time in accordance with the law, could be terminated only on the grounds provided by law - and the law did not provide such grounds.

On the contrary, paragraph 8 of the Resolution of the Verkhovna Rada of Ukraine № 2200-XII of 13 March 1992 "On Acceleration of Land Reform and Privatization of Land" provided in paragraph 8 that "citizens, who were duly provided with land plots in lifelong inheritable possession..., retain their rights to use these land plots until the registration of ownership or land use in accordance with the Land Code of Ukraine.

In the legal literature it is noted that even without this instruction, the relevant rights would be preserved. It is noted that the rules on termination of certain types of land use rights in case of its "non-registration" within certain periods provided for in paragraph 6 of the Resolution of the Verkhovna Rada of Ukraine of 18 December 1990 "On Land Reform", as well as paragraph 6 of Section X of the Land Code Ukraine of 25 October 2001, did not apply to the right of lifelong inheritable ownership of land - they concerned in the first case the rights that arose before the entry into force of the Land Code of the Ukrainian SSR, and in the second case - the right of permanent use. In addition, both of these provisions were later declared unconstitutional (decision of the Constitutional Court of Ukraine of 22 September 2005 № 5-rp / 2005 in the socalled case on permanent use of land plots). 33

In general, the fact that an entity that has acquired the right of lifelong inheritable possession, with the expiration of the rules on the basis of which this right arose, continued to have this right, is not questioned in legal doctrine or law enforcement practice. In turn, the conclusion on the "preservation" of the right of lifelong inheritable possession necessarily implies that the scope of this right in the absence of any indication to this in the law was also not narrowed.

The corresponding title ("right of lifelong inherited ownership of land") differed from another title - the right of permanent use. These titles were mentioned in the Land Code of the Ukrainian SSR of 18 December 1990 (in the original version) as different phenomena of the same order (separate titles) - compare Art. 6 "Land ownership" and Art. 7 "Land use". Permanent use was not a general concept of the right of lifelong inheritable possession, it was about different legal constructions, different property rights. Therefore, it is considered that there are no grounds to apply the rules on permanent use to the relationship regarding the right of lifelong inheritable possession of land.

33 Rishennja Kostytuzijnogo Sudu Ukrainy vid 22 veresnja 2005 r. U spravi za konstytuzijnym podannam (sprava pro postijne koystuvannja zemeknymy dilyankamy), sprava N 1-17-2005 // Elektronnyj resurs. Reshym dostupy: https://zakon.rada.gov.ua/laws/main/v005p710-05. 
R. A. Maydanyk, N. I. Maydanyk \& N. R. Popova - Peculiarities if the Usufruct in the Countries of ...

Given that the repeal of the legislation on the right of lifelong inheritable possession of land did not lead to the loss or narrowing of the scope of this right, its content and scope should be determined by the legislation in force at the time of its occurrence.

From the very name of the title ("right of lifelong inheritable possession") it followed that this right could be inherited. The possibility of inheritance was also provided for in Art. 55 of the Code, according to Part 1 of which "[in] the death of a citizen who ran a peasant (farmer) farm, the right to own land is transferred to one of the heirs." The removal of the relevant provisions from the legislation did not affect the nature, content and scope of the rights that have already arisen. 34

In its content, lifelong inherited possession and permanent use largely coincide. The subjects of these real rights to another's property exercise both possession and use of the encumbered land plot. The right of permanent use of land does not provide for the right to inherit the land, in contrast to the lifelong inheritable possession of the latter. They differ, first of all, in the subjective composition, and, moreover, in the reasons for their occurrence. 35 In this regard, permanent use and lifelong inheritable possession in their content are organically integrated into the design of personal possession for use (usufruct) and can be considered as separate varieties, established exclusively for land that is in state and communal ownership. ${ }^{36}$

Similar to the usufruct are provided by the Commercial Code of Ukraine (Articles 136, 137) the right of economic management and the right of operational management, which are limited property rights of a business entity or other business entity that owns, uses and disposes of property assigned to it by the owner (by his authorized body), with the restriction of the authority to dispose of certain types of property with the consent of the owner in cases provided by the Commercial Code and other laws.

The property of a state unitary enterprise, which is in state ownership, is fixed on the right of economic management or the right of operative management. A state unitary enterprise is a legal entity formed by a competent body of state power on an administrative basis on the basis of a separate part of state property and falls within the scope of its management. State unitary enterprises act as state commercial enterprises or state-owned enterprises. The property of a state commercial enterprise is assigned to it on the right of economic management. The property of the state-owned enterprise is assigned to him on the right of operational management in the amount specified in the charter of the enterprise. The body, the management of which includes the state enterprise, controls the use and preservation of property belonging to the enterprise, and has the right to seize from the state enterprise property that is not used or misused, and dispose of it within its powers (Article 77 of the Commercial Code of Ukraine).

The right of economic management and the right of operational management are unknown to European countries "published" property rights.

It is advisable to abandon the rights of economic management and operational management provided by the legislation of Ukraine, as they do not correspond to the concept of property rights and are essentially based on the idea of exercising administrative power of the

34 Miroshnichenko, A. M. Schodo zastosuvannja norm prava, yaki reguluut vidnosyny schodo prava dovichnogo uspadkovuvanogo volodinnja zemelnoyu dilankoyu // [Elektronnyj resurs]. - Resgym dostupu:

https://protocol.ua/ua/naukoviy visnovok shchodo zastosuvannya norm prava yaki regulyuyut vid nosini shchodo prava dovichnogo uspadkovuvanogo volodinnya zemelnoyu dilyankoyu/.

35 Sukhanov, E. A. Grashdanskoye pravo Rossiji - chastnoye pravo. M.: Statut, 2008. S. 229.

${ }^{6} 6$ Mazakyan, G. S. Osobennosti pravovoj konstrukzii usufructa d rossijskom, germanskom i franzuskom grashdanskom prave // Yuridicheskaya nauka. 2016. N 2. C. 59. 
owner [state, territorial community] over the property. property rights, which are formed in the system of socialist law and remain unknown to the Western tradition of law.

Instead of these quasi-property rights, the relevant relations should be regulated by similar in functional purpose, but generally recognized developed legal rights property rights - the right of usufruct, long-term lease, trust management and trust property.

This approach is reflected in modern acts of civil codification (in particular, in the Civil Codes of Georgia, Lithuania, etc.), which abandoned both the construction of a unitary state/municipal enterprise, and the right of economic management and the right of operational management ${ }^{37}$.

\subsubsection{The place of usufruct in the system of property law of Ukraine}

By its legal nature, the usufruct in the law of Ukraine should be recognized as an independent, different from the easement, real property right for personal use. In this regard, the general provisions of the Civil Code of Ukraine on property rights must be extended to the usufruct, unless otherwise follows from the provisions of this chapter and the essence of the usufruct. The usufruct serves as a general provision on emphyteusis (the right to use someone else's land for agricultural purposes). In this regard, the provisions of Chapter 32 of the CC of Ukraine on usufruct should be applied to relations under emphyteusis, unless otherwise provided by the provisions of the Central Committee on emphyteusis and does not follow from its essence.

According to its purpose, the legal construction of the usufruct can perform any function of personal possession for the use of another's property. It is especially important that the usufruct is able to perform similar functions to the right of economic management and the right of operational management as property rights. In this context, usufruct is the most acceptable replacement for the right of economic management and the right of operational management, which should be abandoned, given their public law nature and inconsistency with the concept of property rights.

\subsubsection{Model norms of Chapter 32-1 "Uzufruct" of the CC of Ukraine}

The introduction of usufruct in the law of Ukraine should be carried out by supplementing the CC of Ukraine with Chapter 32-1 "Usufruct" (Articles 406-1-406-9), which will contain provisions on the concept of usufruct, its objects, subjects and validity, quasi-usufruct, usufruct of the enterprise and other property, implementation of usufruct, grounds for occurrence and termination, legal consequences of termination of usufruct in the wording proposed below.

Article 406-1 "The concept of usufruct"

(1) The owner of the thing has the right to give another person - a natural or legal person (usufructuary) the right to own and use such a thing, receive its fruits on the same terms as the owner, but with the obligation to preserve the essence of the thing (usufruct). The usufructuary has the right to own the thing, but is not entitled to alienate it.

(2) A usufruct may be established simultaneously or sequentially for the benefit of one or more individuals and legal entities, regardless of the purposes of their activities that exist at the time of the opening of the usufruct.

37 Maydanyk, R. A. Reconsidering of property law in modern terms // Property Law: priorities and prospects. Proceedings of Kyiv legal readings. Kyiv, 22 March 2019 / R. A. Maydanyk, Y. M. Romanyk et al. Edit. R. A. Maydanyk. K.: Alerta, 2019. P. 31. 
R. A. Maydanyk, N. I. Maydanyk \& N. R. Popova - Peculiarities if the Usufruct in the Countries of ...

(3) A usufruct is gratuitous if its payment nature is not directly determined by agreement of the parties or by law.

(4) The general provisions of the Central Committee of Ukraine on property rights shall apply to the usufruct, unless otherwise follows from the provisions of this chapter and the essence of the easement.

The provisions of Chapter 32 "The right to use someone else's land for agricultural purposes" shall apply to relations under emphyteusis, unless otherwise established by the provisions of the CC of Ukraine on emphyteusis and does not follow from its essence.

Article 406-2 "Object of usufruct"

(1) A usufruct may be established on any kind of non-perishable things, movable or immovable, which are in civil circulation and capable of bearing fruit, products and income.

(2) The usufruct extends to all the accessories of the thing provided in the usufruct, as well as to everything that joins it or is included in its composition.

St. 406-3 "Quasi-usufruct"

(1) In the case of installation of usufruct on consumer goods (quasi-usufruct), the latter becomes the property of the usufructuary with the obligation to return the usufruct to the original owner of the thing of the same kind and quality or reimburse their value at the price determined on the day of return.

(2) The usufructuary, in exchange for the consumed things received in the property, is obliged to return to the owner an equal quantity of the things of the same kind and quality received by him after the end of the usufruct, or to reimburse the person who established the usufruct, their value. In order to reimburse the value of consumed things, the price is used, which in comparable circumstances is usually charged for similar things at the end of the usufruct.

Article 406-4 "Usufruct of the enterprise, other property"

(1) The general provisions of this chapter of the Civil Code on usufruct apply to the usufruct of a single property complex of an enterprise or other property. If the property includes consumer goods, they are covered by quasi-usufruct.

Article 406-5 "Establishment of a usufruct"

(1) The usufruct may be established on the basis of law or deed (contract or will).

Article 406-6 "Term of usufruct"

(1) A usufruct may be established for a period not longer than until the death of a natural person or the liquidation of a legal entity in whose favor the usufruct is established, unless a shorter period is established by law or contract.

(2) The term of usufruct established in favor of a legal entity may not exceed thirty years.

(3) The term of validity of the usufruct may be set by the parties depending on the achievement of a certain age by a third party.

(4) Any contract by which the usufructuary is established for an indefinite period and which is subject to transfer in case of death or liquidation of the usufructuary is null and void.

Article 406-7 "Implementation of usufruct" to exercise it.

(1) The object of transfer and alienation may be both the usufruct itself and the right 
(2) The right to exercise usufruct is separate from usufruct and may be transferred to third parties on the basis of paid or unpaid transactions.

(3) The usufruct may be transferred to another person, including by way of universal succession or on the basis of a transaction.

(4) The transfer or alienation of the usufruct is carried out without the consent of the owner of the encumbered property. The transfer or alienation of a usufruct, the object of which is a land plot intended for agriculture, or real estate for business or other economic purposes, is carried out with the consent of the owner of the encumbered property. In the absence of appropriate consent, the usufructuary has the right to enter into such an agreement on the basis of a court decision, if he proves in court that he will not harm the interests of the owner.

(5) In the case of simultaneous purchase and sale of usufruct and property rights without the right of use, the price is divided between the usufruct and this right in proportion to the corresponding value of each of these, unless the parties agree to include usufruct in the price. By mutual agreement of the parties to the contracts of sale of usufruct and property rights encumbered by him may use the proceeds from the sale of usufruct and property rights to purchase new property and acquire previously terminated property rights to this property by replacing the subject of usufruct. In the event that the usufructuary and the owner of the property encumbered by the usufruct alienate their rights to the person who acquires the qualities of usufructuary and owner, the encumbrances of ownership and usufruct shall cease.

Article 406-8 "Termination of usufruct"

The usufruct is terminated in case of: (1) death of the usufructuary; (2) unilateral waiver by the usufructuary of his right only if it is free of charge; (3) death of encumbered property; (4) expiration of the term for which it was established; (5) coincidence in one person of the owner and usufructuary (merger in one person of qualities of usufructuary and owner); (6) alienation of usufruct to another person; (7) non-use of usufruct for 30 years; (8) abuse of the usufructuary's right; (9) deterioration of the encumbered property, as a result of which it becomes unusable for its intended purpose; (10) Social usufruct, which is established for the benefit of persons living with the owner of the dwelling and have the right under family law to require this owner to pay alimony, is valid for the duration of the obligation of the owner of real estate to provide maintenance to such persons. Accordingly, the termination of the relevant obligation automatically entails the termination of the social usufruct. A social usufruct, which is established for the benefit of persons living together with the owner of the dwelling and who are dependent on the latter, is valid for life, unless another term is established by a court decision.

Article 406-9 "Legal Consequences of Termination of Usufruct"

(1) After the termination of the usufruct, the usufructuary is obliged to return to the owner the property which he owns by virtue of his right to the usufruct, in the condition in which it is located.

(2) In case of death or damage of property due to the fault of the usufructuary, the latter is obliged to reimburse the owner for the damages caused in this connection. excluded from it.

(3) If the usufruct is registered in the public register, the terminated usufruct shall be

\section{Conclusions}

(1) Despite the fact that the legal structure of usufruct in modern Roman and German law is generally built on the model of Roman usufruct, analysis of the legislation of specific legal systems of this legal family shows some differences, including constitutive features, types and 
terms, establishment and termination, as well as the possibility of transfer or alienation of this right to others.

(2) The right of permanent use and the right of lifelong inheritable possession provided by the law of Ukraine similar to the usufruct are covered by the concept of usufruct and can be considered as its separate varieties established exclusively concerning the land plots which are in the state and municipal property.

(3) It is expedient to refuse the rights of economic management and operative management provided by the legislation of Ukraine as they do not correspond to the concept of property rights. Instead of these quasi-property rights, the relevant relations should be governed by the generally recognized property rights in Romano-Germanic law, in particular the law of usufruct.

\section{Acknowledgements}

This research did not receive any specific grant from funding agencies in the public commercial, or not-for-profit sectors.

The authors declare no competing interests.

\section{References}

Antonov, B. A. (2006). Formirovaniye instituta usufrukta d germanskom prave: diss. ...kand. yurid. yauk. M.

... (2020). Concept of updating the civil code of Ukraine. Kyiv: Publishing House 'ArtEk', 128p.

... (n.d). Cour de Cassation, IFrananon Franannon Franan зуфвла dame Malet. URL: https://www.courdecassation.fr.

Doshdev, D. V. (1996). Rimskoye chastnoe pravo: Uchebnik dlja vuzov. M.: INFRA-M; NORMA.

... (1908). Franzuskiy grashdanskuj kodeks, SPb.: Yuridicheskiy zentr 'Press', 2004. Shevejzarskoje grashdansjoye ulosheniye. Chast chetvertaya. Veschnoye pravo // Shurnal Ministerstva yustiziyi. N 8.

... (2000). Germanskoye grashdanskoye ulosheniye ot 18 avgusta $1897 \mathrm{~g}$. (s posled. izm.) // Germaskoye pravo. Ch. 1. Grashdanskoye ulosheniye. M.: MZFER, 1996; Grashdanskiy kodeks Niderlandov. Knigi 2, 3, 5 i 6 / Per. V. Fershtman; Otv. Red. F. J. M. Feldbrugge. 2-e iad. Lejden: Institut vostochno-yevropejskogo prava i rossiyevedeniya; Lejdenskij universitet, yuruduchesliy fakultet.

... (2015). Grashdanskoye ulosheniye Germanii. Vvodnuy zakon k Grashdanskomu ulosheniyu: per. s nem. / sost. V. Bergman, M.: Infotropik Media, S. 339.

... (2012). Grashdanskiy Kodeks Franziyi (Kodeks Napoleona) - Code civil des Français (Code Napoléon) / per. S fr. V. N. Zahvatayev. M: Infotropik Media, S. 203.

... (2018). Grashdanskiy kodeks Moldovy. Zakon Respubliki Moldova, v redakziyi Zakona Respubliki Moldova N 133 ot 15.11.2018 g. // [Elektronnyi resurs]. - Reshym dostupa: http://www.legis.md/cautare/rezultate/112573.

... (n.d.). Grashdanskij kodeks Franzii (kodeks Napoleona) - Code civil des Français (Code Napoléon). S. 210. 
Grebennikov, A. D. (2012). Pravo lichnogo polsovladeniya $v$ svete poloshenij, ustanavlivayemych proyektom Grashdanskogo kodeksa Rossijskoq federazii // Notarius. N 5.

Grebennikov, A. D. (n.d.). Right of personal usufruct in the light of the provisions established by the draft amendments of the Civil Code of the Russian Federation. URL: https://centerbereg.ru/b2890.html.

Gromov, S. A. (2011). Usufruct: yuridicheskaya konstrukziya i veschnoye pravo // Veschenye prava: postanovka problem i jeyo resheniye: sb. St. / otv. red. M. A. Roshkova. M.: Statut, S. 197.

... (2009). Konzepziya razvitiya grashdanskogo zakonodatelstva Rossijskoq Federazii (odobrena Sovetom pri Presidente FR po kodifikazii o sovershenstvovaniyu grasgdanskogo zakonodatelstva 07.10.2009) // Vestnik VAS RF. N 11 // SPS 'KosultantPlus. Pressa i knigi’.

... (2009). Konzepziya razvitiya grashdanskogo zakonodatelstva Rossijskoq Federazii (odobrena Sovetom pri Presidente FR po kodifikazii o sovershenstvovaniyu grasgdanskogo zakonodatelstva 07.10.2009) // Vestnik VAS RF. N 11 // SPS 'KosultantPlus. Pressa i knigi'.

... (2009). Konzepziya rasvitiya grashdanskogo zakonodatelstva Rossijskoq Aederazii (odobrena Sovetom pri Presidente RF po kodifikazii I sivershenstvovaniyu grashdanskogo zakonodatelstva 07.10.2009) // Vestnil VAS RF. N 11 // SPS ‘KonsultantPlus. Pressa i knigi’.

Maydanyk, R. A. (2019). Usufruct: European and Ukrainian Law // Problemy vdoskonalennja pryvatnopravovyh mekhanizmiv nabuttja, peredachi, zdijsnennja ta zahysty subjektyvnyk prav : materialy nauk.-prakt. Konf., prusvjach. Pamjati prof. Ch. N. Azimov ta 20-richu z dnja stvorennja kaf. zyv. Prava N 2 (Kharkiv, 29 lystop. 2019 r.). - Kharkiv: Pravo - 396s.

Maydanyk, R. A. (2019). Reconsidering of property law in modern terms // Property Law: priorities and prospects. Proceedings of Kyiv legal readings. Kyiv, March 22, 2019 / R. A. Maydanyk, Y. M. Romanyk et al. Edit. R. A. Maydanyk. K.: Alerta, 260 p.

Mazakyan, G. S. (2016). Osobennosti pravovoj konstrukzii uzufrukta v rossijskom, germanskom $i$ franzuskom prave // YUridicheskaya nauka. N 2. S. 58-65.

Mazakyan, G. S. (2018). Pravo lichnogo polzovladeniya: problem teoriyi i praktiki: duss. ...kand. Yurid. Nauk. - M., 225 s. [Elektronnyj resurs]. - Reshim dostupa: https://msal.ru/upload/main/oodisser/2016/Matsakyan/\%Do\%94\%Do\%B8\%D1\%81\%D1\% 81\%Do\%B5\%D1\%80\%D1\%82\%Do\%Bo\%D1\%86\%Do\%B8\%D1\%8F\%20\%Do\%9C\%Do\%Bo\% D1\%86\%Do\%Bo\%Do\%BA\%D1\%8F\%Do\%BD.pdf

Miroshnychenko, A. M. (2007). Zemelne pravo Ukrainy: Navchalnuy posibnyk. - K.: Instytut zakonodavstva Verhovnoyi Rady Ukrainy - 432 s.

Miroshnichenko, A. M. (n.d.). Schodo zastosuvannja norm prava, yaki reguluut vidnosyny schodo prava dovichnogo uspadkovuvanogo volodinnja zemelnoyu dilankoyu // [Elektronnyj resurs]. Resgym dostupu:

https://protocol.ua/ua/naukoviy visnovok shchodo zastosuvannya norm prava yaki reg ulyuyut vidnosini shchodo_prava dovichnogo uspadkovuvanogo_volodinnya zemelnoyu dilyankoyu/

Novizkiy, I. B. (2003). Rimskoye pravo: Uchebnik dlya vuzov. M.: IKD 'Zerzalo-M', 2008. Doshdev D. V. Rimskoye chastnoye pravo: Uchebnik dlya vuzov /Pod red. V. S. Nersesyanz. M.: Norma, S. 244.

Pavlenko, O. O., \& Krasytska L. V. (2013). Usufrukt yak obmeshene rechove pravo // Visnyk studentskoho naukovoho tovarystva DonNU imenu Vasylya Stusa. Tom 1 N 5, S. 82-87. [Elektronnyj resurs]. - Reshym dostupu: https://jvestnik-sss.donnu.edu.ua/article/view/1213.

... (2012). Proyekt Federalnogo zakona N 47538-6 'O vnesenii izmenenij v chasti pervuju, vtoruju, tretju i chetvertuju Grashdanskogo kodeksa Rossijskoj Federazii, a takshe v otdelnyje zakonodatelnje akty Rossijskoj Federazii' (prinataya GD FS RF v pervom chtenii 27.04/2012) // SPS 'KonsultantPlus'. 
R. A. Maydanyk, N. I. Maydanyk \& N. R. Popova - Peculiarities if the Usufruct in the Countries of ...

... (2016). Proyekt Federalnogo zakona N 47538-6 'O vnesenii izmenenij v chasti pervuju, vtoruju, tretju i chetvertuju Grashdanskogo kodeksa Rossijskoj Federazii, a takshe v otdelnyje zakonodatelnje akty Rossijskoj Federazii' (prinataya GD FS RF v pervom chtenii 27.04/2012) // SPS 'KonsultantPlus'.; Mazakyan G. S. Osobennosti pravovoj konstrukzii uzufrukta v rossijskom, germanskom i franzuskom prave // YUridicheskaya nauka. 2016. N 2. S. 58-65.

... (2000). Reformuvannja zemelnych vidnosyn v Ukraini, S. 69.

... (2005). Rishennja Kostytuzijnogo Sudu Ukrainy vid 22 veresnja 2005 r. U spravi za konstytuzijnym podannam (sprava pro postijne koystuvannja zemeknymy dilyankamy), sprava N 1-17-2005 // Elektronnyj resurs. - Reshym dostupy: https://zakon.rada.gov.ua/laws/main/vo05p710-05.

... (2005). Rishennja Kostytuzijnogo Sudu Ukrainy vid 22 veresnja 2005 r. U spravi za konstytuzijnym podannam (sprava pro postijne koystuvannja zemeknymy dilyankamy), sprava N 1-17-2005 // Elektronnyj resurs. - Reshym dostupy: https://zakon.rada.gov.ua/laws/main/vo05p71005. Miroshnichenko A. M. Schodo zastosuvannja norm prava, yaki reguluut vidnosyny schodo prava dovichnogo uspadkovuvanogo volodinnja zemelnoyu dilankoyu // [Elektronnyj resurs]. - Resgym dostupu:

https://protocol.ua/ua/naukoviy_visnovok_shchodo_zastosuvannya_norm_prava_yaki_reg ulyuyut vidnosini_shchodo_prava_dovichnogo_uspadkovuvanogo_volodinnya zemelnoyu dilyankoyu/.

... (n.d.). Shlyahy pidvyshennja efektyvnosti upravlinnja zemelnymy resursamy mist Ukrainy. - K: IRZ.

Smitjuh, A. V. (2020). Schodo uzufrukta korporatyvnyh paiv (chastok, akzij) // PRAVO I SUSPILSTVO, N 3 / 2020/ - S. 74-79. [Elektronnnyj resurs]. Reshym dostupu: http://www.pravoisuspilstvo.org.ua/archive/2020/3 2020/13.pdf.

Sukhanov, Y. A. (2008). Grashdanskoye pravo Rossii - chastnoye pravo. M.: Statut, S. 221.

Sukhanov, E. A. (2008). Grashdanskoye pravo Rossiji - chastnoye pravo. M.: Statut, S. 229.

Sukhanov, E. A. (2008). Grashdanskoye pravo Rossïi - chastnoye pravo. M.: Statut, S. 229.

Vasilevskaya, L. Y. (2008). Ucheniye o veschnuh sdelkah po grashdanskome pravu. M.: Statut, S. 360. 